\title{
Movement and longitudinal distribution of a migratory fish (Salminus brasiliensis) in a small reservoir in southern Brazil
}

\author{
Lucas De Fries ${ }^{1}$, Lisiane Hahn², Bruna Arbo Meneses ${ }^{1}$, Luís Fernando da Câmara², \\ Fernando Gertum Becker ${ }^{1}$ and Sandra Maria Hartz ${ }^{1}$
}

\begin{abstract}
We investigated whether the movement and distribution of the migratory fish, Salminus brasiliensis, were affected by a small reservoir. We also examined how movement and distribution were related to water temperature, flow, and rainfall. In December 2011 and January 2012, 24 individuals were captured downstream from the dam, tagged with radio transmitters and released in the reservoir $\left(5.46 \mathrm{~km}^{2}\right.$ total area). After being released in the reservoir, 18 of the 24 tagged fish travelled upstream, taking an average of 16.6 days to leave the reservoir, with daily movements varying from $<5 \mathrm{~km} /$ day to $>24$ $\mathrm{km} /$ day. However, only seven tagged specimens (29.16\%) returned to the lower reservoir section, while the rest remained in the intermediate and upper reservoir sections. Longitudinal distributions and movements were positively related to both upstream flow into the reservoir and water temperature. We found evidence that $S$. brasiliensis can recognize the longitudinal gradient and is able to continue its upstream migration. On the other hand, the reservoir negatively affected downstream movements, possibly because disorientation prevented movement to the lower reservoir section. Based on these results, we suggest that the impact of small reservoirs on migratory fish species should be objectively addressed in environmental impact assessments and management programs.
\end{abstract}

Keywords: Environmental impact, Fragmentation, Habitat use, Hydroelectric power, Radio telemetry

Neste estudo investigamos se o movimento e distribuição do peixe migrador, Salminus brasiliensis, são afetados por um pequeno reservatório. Também avaliamos como movimento e distribuição se relacionam com a temperatura da água, fluxo e pluviosidade. Em dezembro de 2011 e janeiro 2012, 24 indivíduos foram capturados a jusante da barragem, marcados com radiotransmissores e liberados no reservatório $\left(5,46 \mathrm{~km}^{2}\right)$. Depois de soltos, 18 dos 24 peixes marcados se deslocaram para montante, levando em média 16,6 dias para ultrapassar o reservatório com movimentos diários variando de $<5 \mathrm{~km} /$ dia a $>24 \mathrm{~km} /$ dia. Entretanto, apenas sete $(29,16 \%)$ dos peixes marcados retornaram para seção inferior do reservatório, a maior parte mantendo-se nas seções intermediárias e superiores do reservatório. Distribuição longitudinal e movimento dos peixes foram relacionados positivamente com o fluxo de montante dentro do reservatório e com a temperatura da água. Assim, encontramos evidências que $S$. brasiliensis pode reconhecer o gradiente longitudinal e continuar sua migração ascendente. Por outro lado, nossos resultados também indicam que o movimento para jusante foi afetado, possivelmente, devido à desorientação, o que impede que os indivíduos alcancem as seções inferiores do reservatório. Com base nos resultados, sugerimos que impactos sobre peixes migratórios devem ser objetivamente abordados em avaliações ambientais e gestão ambiental de pequenos reservatórios.

Palavras-chave: Fragmentação, Hidrelétricas, Impacto ambiental, Radiotelemetria, Uso de habitat.

\section{Introduction}

The construction of dams and their associated reservoirs has been a major concern for biodiversity conservation because they alter river communities and environments (Nilsson et al., 2005; Agostinho et al.,
2008). Migratory neotropical fish have been particularly affected by the construction of dams (Agostinho et al., 2008; Gubiani et al., 2010) since they need to perform extensive migratory movements $(>1,000 \mathrm{~km}$, Godoy, 1975; Agostinho et al., 2003; Barthem et al., 2017) between critical habitats. Fishways have long been

\footnotetext{
${ }^{1}$ Programa de Pós-Graduação em Ecologia, Universidade Federal do Rio Grande do Sul, Departamento de Ecologia, Av. Bento Gonçalves, 9500, Seção 4, Prédio 43422, Caixa Postal 15007, 91501-970 Porto Alegre, RS, Brazil. (LDF) lucas.defries@yahoo.com.br (corresponding author), Dhttps://orcid.org/0000-0001-8361-2608; (BAM) brunameneses@gmail.com, Dhttps://orcid.org/0000-0002-8144-5786; (FGB) fgbecker@ufrgs.br, Ohttps://orcid.org/0000-0002-8295-2691; (SMH) sandra.hartz@ufrgs.br, @ohttps://orcid.org/0000-0002-6536-1072 ${ }^{2}$ Neotropical Consultoria e Assessoria Ambiental, Rua Cesário Rossetto, 182, 99074-210 Passo Fundo, RS, Brazil. (LH) lisiane@ neotropical.com.br, Đhttps://orcid.org/0000-0002-1652-8294; (LFC) 1fc@neotropical.com.br, @https://orcid.org/0000-0002-7804-1043
} 
considered an environmental solution to the interruption of fish migratory routes by dams. However, for the conservation of demographic and genetic dynamics, fish movement through fishways and reservoirs must be efficient in both downstream and upstream directions (Pelicice et al., 2015). There is evidence that fishways are used only unidirectionally (see the critical reviews from Noonan et al., 2012 and Pompeu et al., 2012). Reservoirs can potentially create an additional barrier for migratory fish movements, as they represent a diffuse hydraulic and limnological gradient that influences fish behavior and negatively affects downstream movements (Pelicice et al., 2015). In large reservoirs, downstream fish movement is considered a more critical problem than upstream movement (Antonio et al., 2007; Makrakis et al., 2007a, 2007b; Makrakis et al., 2012).

Smaller impoundments could have hypothetically less-severe impacts on adult fish movements because hydraulic and limnological gradients are much shorter and weaker than those of larger impoundments (Pelicice et al., 2015). Pelicice et al. (2015) suggested that large reservoirs have a detrimental effect on adult migratory fish when (i) "migratory/rheophilic fish remain in the upper reaches of large impoundments and have a low abundance within the reservoir" and (ii) "adult fish actively avoid the inner areas of the reservoir". These predictions, however, refer to reservoirs of much larger dimensions than the one addressed here, so their validity for smaller reservoirs should still be investigated. If small reservoirs have little effect on the movement of adult migratory fish, more effort could be allocated to the efficient passage through the dams and to understanding the effects of dams on early life stages.

In this study, we investigated the movement of Salminus brasiliensis (Cuvier, 1816), one of the main migratory species of the Paraná-Paraguay River basin, in a small reservoir located in southern Brazil. Salminus brasiliensis is popularly known as "dourado", and it occurs in rivers throughout the La Plata River basin, including the Paraná, Paraguay, and Uruguay River basins (Lima et al., 2003). This species travels over long distances (Bonetto et al., 1971; Godoy, 1975; Delfino, Baigún, 1985; Sverlij, Ros, 1986; Hahn et al., 2011) to reach spawning sites in the upper stretches of rivers. Despite its wide geographical distribution, $S$. brasiliensis is regionally threatened in the Brazilian state of Rio Grande do Sul (FZB, 2014), mainly as a consequence of river fragmentation by hydropower dams (Reis et al., 2003).

Here, we describe the movements and longitudinal distribution patterns of $S$. brasiliensis individuals captured downstream of the Monjolinho dam in the Passo Fundo River (Uruguay River basin) and released into its reservoir ( $<25 \mathrm{~km}$ long; $5.46 \mathrm{~km}^{2}$ total area). We were interested in investigating whether $S$. brasiliensis migratory movements could be affected by the reservoir.
We addressed the following questions: (1) Do individuals move upstream to leave the reservoir? (2) How long does it take for individuals to move from the dam to the upper portion of the reservoir? (3) What is the mean time individuals spend within and outside the reservoir during a year? (4) Is there a temporal pattern of individual movement and longitudinal distribution in the reservoir? (5) Are the movements and distributions of individuals within the reservoir related to rainfall, water temperature, and/or water inflow?

\section{Material and Methods}

Study area. We investigated the movement and distribution of S. brasiliensis in the Monjolinho reservoir, which is located in the Passo Fundo River $4 \mathrm{~km}$ upstream of its confluence with the Uruguay River in southern Brazil (Fig. 1). This reservoir flooded the confluence of the Passo Fundo and Erechim rivers, and only the latter presents a lotic segment (40 km long) that is potentially viable for upstream migratory fish movements (Fig. 1). There are no other tributaries along this stretch of the Erechim River. The Passo Fundo River has only a short free-flowing stretch $(2.5 \mathrm{~km})$ upstream from the Monjolinho reservoir until reaching a waterfall that is a natural barrier to fish movement (Fig. 1). The upper reservoir-to-river transitional area of the Monjolinho reservoir is influenced by the turbine discharge of the Passo Fundo Hydropower Plant (HPP), which is located $5 \mathrm{~km}$ upstream of the upper end of the Monjolinho reservoir. The Passo Fundo HPP diverts water from the Passo Fundo River reservoir to a powerhouse that is located at the Erechim River, just upstream from the Monjolinho reservoir (see Fig. 1).

The Monjolinho reservoir has a total flooded area of $5.46 \mathrm{~km}^{2}$ and is $24.6 \mathrm{~km}$ long, with a maximum width of $400 \mathrm{~m}$ close to the dam and a width of approximately $50 \mathrm{~m}$ at the upper end of the reservoir. The depth next to the dam is approximately $70 \mathrm{~m}$; the mean depth in the reservoir is $27.5 \mathrm{~m}$; and the mean water residence time is 25 days, expressing the lentic character of the reservoir. The dam is $74 \mathrm{~m}$ high, with a free-overflow spillway that does not have a fish passage system. The power plant has an installed capacity of $74 \mathrm{MW}$ with two Francis-type turbines. Monjolinho HPP started operation in September 2009. In 2011, the Foz do Chapecó HPP, with a dam located downstream of the Monjolinho HPP in the Uruguay River, flooded the mouth of the Passo Fundo River, with part of its reservoir reaching the base of the Monjolinho dam (Fig. 1).

The regional mean annual air temperatures range from $18^{\circ} \mathrm{C}$ to $20^{\circ} \mathrm{C}$. The mean annual rainfall ranges from 1750 to $2000 \mathrm{~mm}$ and mainly falls between August and October, although there is no typical dry season (IBGE, 1990). 


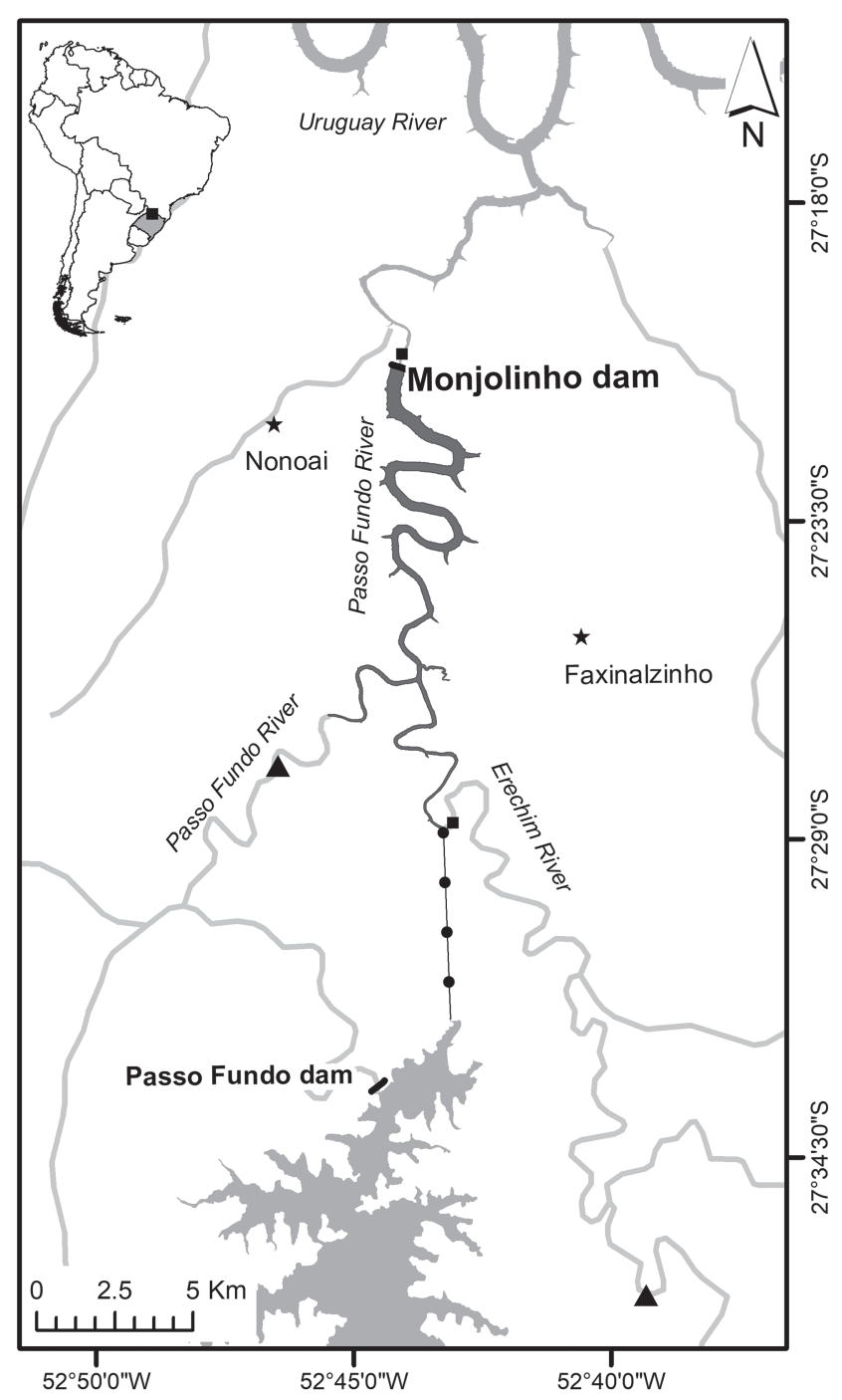

Fig. 1. Map of the study area in the Uruguay river basin located in southern Brazil. Stars = cities; triangles = natural barriers; squares $=$ positions of fixed radio telemetry stations; line with dottes $=$ duct that takes water from the Passo Fundo power house into the Monjolinho reservoir. The confluences of the Passo Fundo and Erechim rivers and of the Passo Fundo and Uruguay rivers have been flooded by the Monjolinho and Foz do Chapecó reservoirs. Dark gray represents the area that was monitored in this study.

Fish sampling and tagging. A total of 24 specimens were included in this study: 2 were captured and tagged in January and February 2011, and 22 were captured and tagged from the $26^{\text {th }}$ of December 2011 to the $9^{\text {th }}$ of January 2012. The mean fish size (total length) was $609 \mathrm{~mm}$ (range $=490-750 \mathrm{~mm}, \mathrm{SE}=84.6 \mathrm{~mm}$ ), and the mean fish weight was $2,798 \mathrm{~g}$ (range $=1040$ to $5004 \mathrm{~g} ; \mathrm{SE}=1254 \mathrm{~g}$; Tab. 1). The mean tag/fish weight ratio in water was $0.30 \%$ (range $=0.13-0.64 \%$ ).

All fish were captured $200 \mathrm{~m}$ downstream from the Monjolinho dam using a hook and line with artificial bait. Captured fish were kept for $30 \mathrm{~min}$ in a $120 \mathrm{~L}$ tank filled with river water to allow them to recover prior to tagging. Each fish was then anesthetized by immersion in a clove oil solution (eugenol) diluted in river water $(1 \mathrm{ml}$ eugenol to $40 \mathrm{~L}$ water) for 1-3 $\mathrm{min}$. Anesthetized fish were then measured (total length, $\mathrm{mm}$ ), weighed ( $\mathrm{g}$ ) and placed in a surgical holding tray while their gills were continuously irrigated with a maintenance bath of anesthetic solution (1 $\mathrm{ml}$ eugenol to $100 \mathrm{~L}$ of water). Fish were internally tagged with radio transmitters (Lotek Wireless Inc., MCFT2-3A, $16 \times 46 \mathrm{~mm}$; weight in air $=16 \mathrm{~g}$; weight in water $=6.7 \mathrm{~g} ; 2$ $\mathrm{s}$ burst rate; lifetime of 2 years). A $4 \mathrm{~cm}$ ventral incision was made between the pelvic and pectoral fins, through which the radio transmitter was inserted into the body cavity. The incision was closed with four interrupted stitches made with coated 2-0 monofilament sutures (Vicryl, Ethicon J \& J). Fish were then transferred to a $120 \mathrm{~L}$ tank filled with river water to recover $(30 \mathrm{~min})$ prior to release. They were transported by truck $(20 \mathrm{~min})$ and released into the reservoir $900 \mathrm{~m}$ upstream from the dam. A voucher specimen MCP 47336 is available at the Museu de Ciências e TecnologiaPUCRS.

Fish Tracking. Tagged fish were detected using both fixed stations and mobile tracking techniques between January and December 2012. Two fixed radio telemetry stations were installed in the study area: Station 1 was located $200 \mathrm{~m}$ downstream of the Monjolinho dam to detect fish that could have potentially moved downstream through the spillway or turbines, and Station 2 was placed in the powerhouse of Passo Fundo HPP located in the Erechim River. Station 1 was equipped with three Yagi antennas, one 6-element unit that was pointed downstream and two 4-element units, one pointed at the spillway and the other pointed at the powerhouse. Station 2 was equipped with two 4-element Yagi antennas that were pointed at the river channel. All antennas were connected by coaxial cables to a radio receiver (Lotek SRX 600), which recorded signals $24 / 7$.

In addition to the records taken by the fixed stations, fish were detected inside the reservoir by mobile tracking using a 3-element antenna attached to a boat and connected to a GPS equipped radio receiver (Lotek SRX 600). Mobile tracking was performed over 12 months and consisted of 4 to 8 tracking trips/month (Tab. S1) along $24.6 \mathrm{~km}$ (each trip). These tracking trips occurred in the upstream direction, from the dam towards the upper end of the reservoir and the Erechim River, and included a $2.5 \mathrm{~km}$ river stretch upstream from the end of the reservoir in the Passo Fundo River (see Fig. 1). During the tracking events, the entire reservoir was covered at a median speed of $16 \mathrm{~km} / \mathrm{h}$.

Prior to the beginning of the study, we performed detection tests in the study area, as radio telemetry efficiency can be affected by environmental conditions such as depth. These tests were performed in the deeper sections of the reservoir ( 70 meters) next to the dam using a radio transmitter coupled to a buoy that was secured at 
different depths. For each tested depth, we used a GPS to record the coordinates of the first detection signal and the position of the strongest signal. Detection was possible to a depth of $25 \mathrm{~m}$, when the boat was up to 3 meters away from the buoy (Tab. S2).

Environmental variables. During each tracking trip, the water temperature was measured at the water surface and at three different sections along the reservoir (lower, middle and upper sections). The mean monthly temperature for the whole reservoir was then calculated and used in the data analysis. Rainfall data were obtained from the Embrapa-Trigo meteorological station (Passo Fundo, RS, Brazil) approximately $100 \mathrm{~km}$ from the Monjolinho dam. Water inflow $\left(\mathrm{m}^{3} / \mathrm{s}\right)$ data, which were measured at the upper end of the reservoir, were provided by Monel Monjolinho Energetic and represented the summed contribution of river flow and Passo Fundo HPP discharge. Data for the water flow through the turbines of Passo Fundo HPP were provided by ANA (Agência Nacional de Águas, the national water authority in Brazil).

Fish position and movement data. After each mobile tracking expedition and inspection of the fixed stations, data from the receivers were downloaded using the software provided by the manufacturer (Lotek SRX600 Host). The data were then processed to remove background noise and false positives. Only detections with a power $\geq 40$ and a minimum of six records taken in a 2-min interval were considered valid. The position record used for estimating movement and distance from the dam was obtained using the lower gain and higher power of the receiver, following the protocol described by Alves et al. (2007).

All fish detections were plotted on a map of the Monjolinho reservoir using a geographical information system (ArcGIS 10.2, ESRI, Redlands, CA, USA). To do this, the position of each fish and its distance from the Monjolinho dam were extracted from each recorded signal, and the dam was set as the reference point $(0 \mathrm{~km})$. The net displacement (ND) of each fish was calculated as the net distance $(\mathrm{km})$ between its position at time $t_{1}$ and its position at time $t_{2}$. Therefore, ND represents the effective change in the spatial location of a fish after a given time interval. ND may be equal to or less than the total distance traveled by the fish in the time interval (a fish may move back and forth within the reservoir but end up in the same initial location at the end of the recording period, i.e., total distance traveled by the fish $>0$, but ND $=0$ ).

Both upstream and downstream movements were described for each individual fish. Fish were considered to be 'inside the reservoir' whenever they were registered $<24.6 \mathrm{~km}$ upstream from the dam and were considered to be 'outside the reservoir' when they were recorded at the downstream fixed station $(-0.2 \mathrm{~km}$ from the dam) or at the upstream fixed station ( $25 \mathrm{~km}$ from the dam). Fish detected only once at the fixed upstream station (and not detected again by mobile tracking in the next days) were assigned as "outside of the reservoir". In this way, we determined whether each tagged fish (a) left the reservoir and returned later, (b) stayed in (or returned to) the area close to the dam (position $<0.25 \mathrm{~km}$ ) or (c) left the reservoir in the upstream (recorded at the upstream fixed station) or downstream direction (recorded at the downstream fixed station).

To estimate how long each fish took to move from the dam to the upper portion of the reservoir, the time (hours) elapsed between the release date and the first recording at the upstream fixed station was calculated. Linear regression analysis of the number of days elapsed between two consecutive recordings (predictor) and the net displacement (response) of a fish was used to assess whether displacement was time-dependent. In this analysis, we included the net displacement of all fish recorded by mobile tracking. Monthly differences in mean fish displacement $(\mathrm{km})$ and in fish longitudinal position $(\mathrm{km})$ in the reservoir were tested using linear mixed effect models (LMMs) using the month as a fixed-effects variable and specimen identity as a random effect variable. Posteriorly, we used a Tukey post hoc procedure using the glht function from the package Multcomp (Hothorn et al., 2008) in R (R Core Team, 2019). We used package lme4 (Bates et al., 2014) from R (R Core Team 2019) to fit the LMMs and MuMIn (Bartoń, 2019) to calculate the pseudo- $\mathrm{R}^{2}$ value $\left(\mathrm{R}^{2}\right.$-marginal and $\mathrm{R}^{2}$-total). The Package lmerTest (Kuznetsova et al., 2015) was used to test for significance of the variables in the model.

The mean time (days) spent by the tagged fish inside and outside the reservoir was based on the records obtained from both the mobile tracking and the fixed stations. Data from the downstream station helped to determine when the tagged fish left the reservoir in a downstream movement, while data from the upstream station were used to help determine whether the fish left the reservoir in an upstream direction and later returned $\left(\mathrm{T}_{\text {out }}\right)$. Data from mobile tracking were used to determine the time a fish spent inside the reservoir $\left(\mathrm{T}_{\mathrm{in}}\right)$. Whenever the time elapsed since the last record in the fixed station was $>3$ days and no record of the fish was found within the reservoir thereafter, we assumed the fish was removed from our study area. This period of time was defined as the "time spent in an unknown location" $\left(\mathrm{T}_{\text {unknown }}\right)$.

The line density tool from ArcMap 10.2 (ESRI, Redlands, CA, USA) was used to determine the movement density along the reservoir. The analysis of movement density allows visual detection of the spatial patterns of displacement in the reservoir. In this procedure, individual movements were represented as lines drawn between the consecutive positions of each tracked individual. Line density was calculated as the ratio of the sum of the line lengths over the area of a circle (with a $250 \mathrm{~m}$ radius) centered on the centroid of each pixel of an image representing the reservoir's surface (squared pixels with sides $10 \mathrm{~m}$ in length). Line density was therefore expressed in $\mathrm{km} / \mathrm{km}^{2}$, and for interpretation purposes, it was visualized on maps of the reservoir's surface. This was performed for each season: summer (January, February and March), autumn (April, May and June), winter (July, August and September) and spring (October, November and 
December). We examined the within-reservoir movement patterns during the different periods of the year since the study region has a subtropical climate with a relatively clear four-seasonal variation in temperature and daylight hours. To evaluate longitudinal differences in the movement density among seasons, the reservoir was divided along the longitudinal gradient into 10 equal-sized compartments. To test for seasonal differences in movement density, we also employed LMMs, including season as a fixed-effects variable and specimen identity and reservoir section as random-effects variables. Thus, we controlled for the same individual being recorded in different samples and for spatial effects.

Model selection was used to investigate whether the net displacement of $S$. brasiliensis individuals and their longitudinal distribution (distance from the dam) were related to water temperature, water inflow and rainfall. Before model selection, we checked for collinearity between the predictor variables (Pearson correlation). The global model was obtained by LMMs, where all environmental variables were used for fixed effects and individual identity for random effects. The most important models were selected from those produced by the 'dredge' function from the MuMIn package (Barton, 2019) in R (R Core Team, 2019). This function generated a set of models with different combinations of variables, including a null model. The best models were selected using Akaike's information criterion corrected for small sample sizes (AICc), where models with smaller values of delta AICc and higher weights were considered more consistent (Burnham, Anderson, 2002). The relative importance of each variable was extracted using the 'importance' function from the MuMIn package (Barton', 2019). The standardized coefficient of the most important variable was extracted using the 'scale' function (Becker et al., 1988) in R (R Core Team, 2019).

\section{Results}

Upstream and downstream movements. Of the 24 total radio-tagged specimens, 18 (75\%) moved upstream from the reservoir to the Erechim River and later returned to the reservoir (except for the fish coded 14, which had no return record; Tab. 1). Only 7 specimens (29.1\%) moved downstream to the lower portion of the reservoir close to the dam (lower portion $=$ any tracking position situated less than $<250 \mathrm{~m}$ from the dam). Two (8.33\%) of these were detected by Station 1 (downstream of the dam) 10 months after release, and both were continuously recorded there until the last day of the study. On the last tracking day of this study, only 7 specimens were recorded: 5 were in the reservoir and 2 were close to the Passo Fundo HPP powerhouse in the Erechim River (Tab. 1). One fish (code 94) was presumed dead since it was recorded at the release site for the whole study period, while another fish (code 100) was never recorded after its release.

Tab. 1. Data from 24 tagged specimens of Salminus brasiliensis. Code $=$ radio transmitter code, $\mathrm{TL}=\mathrm{Total}$ length, $\mathrm{SL}=$ Standard length, $\mathrm{TW}=$ Total weight, $\mathrm{R}=$ number of records. Upstream and downstream maximum position distances from the dam. Position at the last tracking record: in or out of the reservoir.

\begin{tabular}{|c|c|c|c|c|c|c|c|c|c|}
\hline Code & $\begin{array}{l}\text { Tagging } \\
\text { Date }\end{array}$ & $\begin{array}{l}\text { Release } \\
\text { Time }\end{array}$ & $\begin{array}{c}\mathrm{TL} \\
(\mathrm{mm})\end{array}$ & $\begin{array}{c}\mathrm{SL} \\
(\mathrm{mm})\end{array}$ & $\begin{array}{l}\text { TW } \\
(\mathrm{g})\end{array}$ & $\begin{array}{l}\text { Upstream Maximum } \\
\text { Position }(\mathrm{km})\end{array}$ & $\begin{array}{l}\text { Downstream Maximum } \\
\text { Position }(\mathrm{km})\end{array}$ & $\begin{array}{l}\text { Position in the last } \\
\text { tracking record }\end{array}$ & $\mathrm{R}$ \\
\hline 10 & $12 / 26 / 2011$ & $18: 35$ & 750 & 660 & 5240 & 25 & 0.10 & In & 116 \\
\hline 12 & 01/09/2012 & $21: 40$ & 570 & 450 & 2006 & 25 & 0.87 & Not recorded & 81 \\
\hline 14 & $01 / 21 / 2011$ & $17: 45$ & 710 & 590 & 3940 & 10.71 & 0.08 & Not recorded & 19 \\
\hline 17 & $01 / 21 / 2011$ & $18: 50$ & 520 & 430 & 1640 & 25 & 1.67 & Out & 56 \\
\hline 19 & $01 / 21 / 2011$ & $20: 30$ & 490 & 410 & 1040 & 25 & 3.55 & Not recorded & 25 \\
\hline 20 & 01/07/2012 & $8: 28$ & 710 & 610 & 4500 & 25 & 0.12 & In & 83 \\
\hline 73 & $12 / 27 / 2011$ & $16: 15$ & 540 & 470 & 1700 & 25 & 3.92 & Not recorded & 29 \\
\hline 74 & $12 / 30 / 2011$ & $7: 45$ & 600 & 520 & 2810 & 25 & - & Not recorded & 1 \\
\hline 75 & 01/05/2012 & $8: 49$ & 560 & 470 & 2000 & 25 & 1.65 & Not recorded & 95 \\
\hline 92 & 01/07/2012 & $21: 40$ & 565 & 475 & 1970 & 25 & 0.05 & Not recorded & 62 \\
\hline 94 & 01/08/2012 & $19: 20$ & 500 & 430 & 1400 & - & - & - & - \\
\hline 95 & $12 / 27 / 2011$ & 10:10 & 750 & 650 & 5004 & 25 & 4.28 & In & 102 \\
\hline 97 & $12 / 27 / 2011$ & $18: 48$ & 580 & 500 & 2350 & 25 & 12 & Not recorded & 71 \\
\hline 98 & 01/08/2012 & $10: 05$ & 500 & 420 & 1500 & 25 & 3.44 & Not recorded & 90 \\
\hline 99 & $12 / 27 / 2011$ & $20: 48$ & 590 & 500 & 2009 & 22.51 & 17.16 & Not recorded & 46 \\
\hline 100 & $12 / 26 / 2011$ & $20: 18$ & 660 & 550 & 3200 & - & - & - & - \\
\hline 147 & $02 / 26 / 2011$ & $20: 15$ & 500 & 430 & 1100 & 25 & 0.87 & In & 154 \\
\hline 191 & 01/05/2012 & $8: 49$ & 620 & 530 & 3500 & 25 & 0.42 & In & 98 \\
\hline 194 & $12 / 26 / 2011$ & $19: 33$ & 690 & 600 & 3570 & 25 & -0.2 & Not recorded & 35 \\
\hline 195 & 01/09/2012 & $20: 33$ & 710 & 600 & 4320 & 25 & 0.23 & Not recorded & 64 \\
\hline 198 & $12 / 29 / 2011$ & $19: 48$ & 630 & 530 & 2970 & 25 & 3.56 & Not recorded & 42 \\
\hline 200 & $01 / 08 / 2012$ & $8: 45$ & 670 & 570 & 3600 & 16.03 & -0.2 & Not recorded & 31 \\
\hline 201 & $01 / 08 / 2012$ & $19: 20$ & 530 & 450 & 1900 & 25 & 3.42 & Out & 86 \\
\hline 202 & $12 / 27 / 2011$ & $20: 48$ & 680 & 590 & 3890 & 25 & 0.78 & Not recorded & 80 \\
\hline
\end{tabular}


Time spent inside and outside the reservoir. After release, the mean time until individuals left the reservoir in the upstream direction and were detected next to the Passo Fundo HPP powerhouse was $16.6 \pm 11.54$ days $($ minimum $=1.12$, maximum $=44.12$ ). Throughout the study period, tagged fish spent longer in the reservoir $(183 \pm 53.5$ days, $\min =60$, $\max$ $=258)$ than outside the reservoir in the Erechim River (49.4 \pm 29.14 days, $\min .=3$, $\max .=132$; Fig. 2 ).

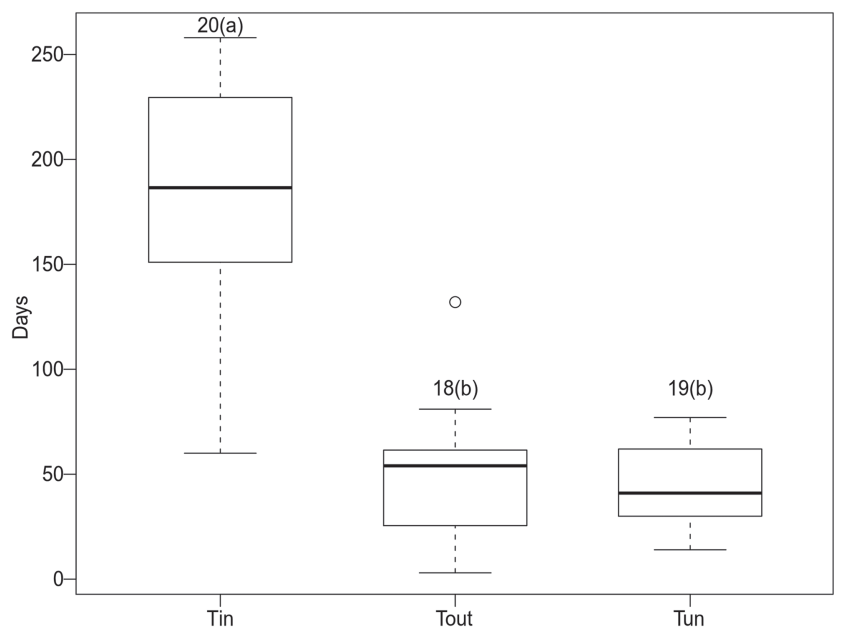

Fig. 2. Total time spent by dourados (Salminus brasiliensis) in the reservoir $\left(T_{i n}\right)$, total time spent in an unknown location $\left(\mathrm{T}_{\mathrm{un}}\right)$ and total time spent outside of the reservoir in a stretch of the upstream Erechim river $\left(\mathrm{T}_{\text {out }}\right)$. ANOVA with permutation tested for differences among groups $\left(\mathrm{F}_{(2,54)}\right.$ $=87.17 ; \mathrm{p}<0.0002)$. The numbers above the plots represent the number of individuals. Different letters above the plots represent significant differences according to Tukey's test. Circles represent outlier values; the heavy horizontal line crossing the box is the median; the bottom and top of the box are the lower and upper quartiles, respectively; and the whiskers are the minimum and maximum values.

Individual net displacement and longitudinal distribution. Some fish moved very actively, traveling relatively long distances in short time intervals, with net displacements of more than $10 \mathrm{~km}$ in 1-3 days (Fig. 3). One individual was able to travel almost $25 \mathrm{~km}$ within one day ( $a$, in Fig. 3). Net displacement based on positions recorded after a large time interval (e.g., Fig. 3, $c$ and $d$ ) does not represent precise estimates of movement velocity, as multiple up-and-down displacements may have occurred across the reservoir.

Individual net displacement varied during the study period $(\mathrm{F}=23.57 ; \mathrm{p}<0.0001)$ and was particularly high in October (median $~ 14$ km; Fig. 4). Smaller values of net displacement (predominantly less than $5 \mathrm{~km}$ ) were observed during autumn and winter (April to September). The total variance explanation of the models was high in models with and without random effects (individual identification), and the difference between the two was negligible (marginal $\mathrm{R}^{2}$ marginal $=0.55 /$ total $\mathrm{R}^{2}=0.59$ ).

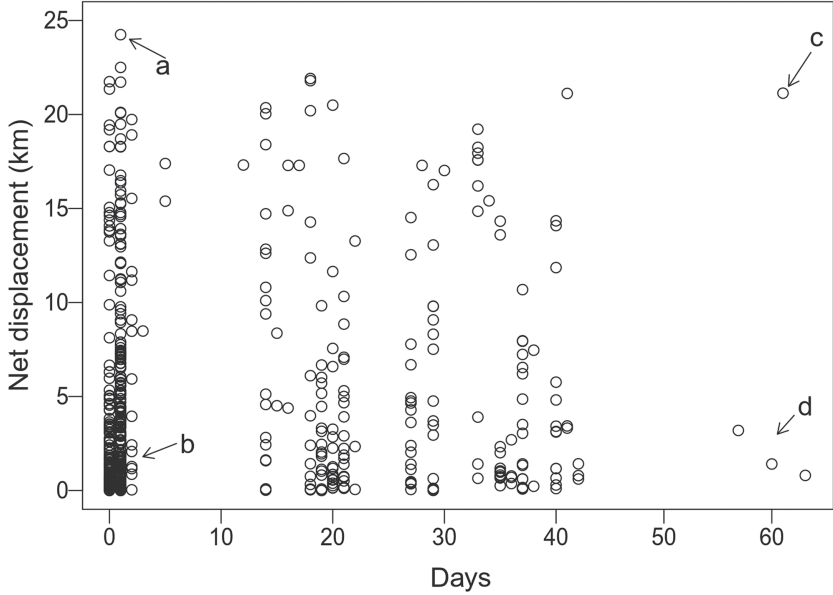

Fig. 3. Observed values of individual net displacement for Salminus brasiliensis in the Monjolinho reservoir. Each dot represents a displacement event; more than one record from the same individual may appear in the plot. a) The individual moved a large distance in a very short time, b) the individual moved a small distance in a short time, c) the individual position moved at least $20 \mathrm{~km}$ within 60 days and d) the individual may have moved only a small distance in a 60-day period. Note: net displacement based on large time intervals (e.g., events $c$ and $d$ ) ignore multiple movements that may have occurred within the time interval (see main text).

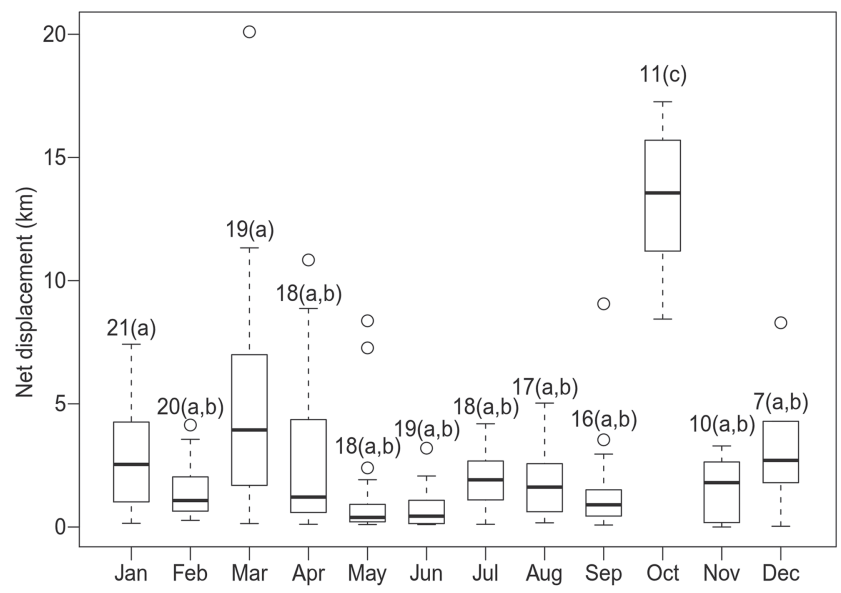

Fig. 4. Net displacement of dourados (Salminus brasiliensis) in the Monjolinho reservoir. The numbers above the plots represent the number of individuals. The letters above the plots represent differences or similarities according to Tukey's test, which was performed after a linear mixed effect model $(\mathrm{F}=23.57)$. Circles represent outlier values; the heavy horizontal line crossing the box is the median; the bottom and top of the box are the lower and upper quartiles, respectively; and the whiskers are the minimum and maximum values.

The longitudinal position of the fish, measured as the distance from the dam, also varied throughout the study period $(F=16.5 ; p<0.0001 ;$ Fig. 5a). Fish were generally 
recorded closer to the dam (although still at a $>5 \mathrm{~km}$ distance) in autumn and winter between the months of May and September, which coincided with their period of lower net displacement (Fig. 4 and Fig. 5a). During spring and summer (October to March), the fish were generally found in the upper portion of the reservoir. The total variance explanation of models not controlled for specimen identity was $39 \%$ (marginal $\mathrm{R}^{2}=0.39$ ); however, when we controlled for specimen identity, it increased to $59 \%\left(\mathrm{R}^{2}\right.$ total $=0.59$ ).

Line density differed among seasons $(F=70.65$; $\mathrm{p}<0.0001$ ), indicating that the spatial distribution of movement was seasonally variable in the reservoir (Fig. 6). The model, not controlling for random effects, presented an explanation of $17 \%\left(\mathrm{R}^{2}\right.$ marginal $\left.=0.17\right)$, which increased to $37 \%$ after controlling for random effects $\left(\mathrm{R}^{2}\right.$ total $=0.37$ ). In summer, the movement density was higher and concentrated in the upper portion of the reservoir, as individual movements were mainly short-ranged and spatially restricted. In contrast, in autumn and winter, the movement density was also short and spatially restricted but was concentrated in the lower portion of the reservoir. In spring, the movement density was high over a large section of the reservoir, suggesting that the fish moved widely throughout the reservoir (Fig. 6).
Movement and environmental variables. The abiotic factors in the reservoir fluctuated seasonally. There was a clear contrast in the water temperature and water inflow between summer and winter, while the autumn and spring months could be described as transitional periods (Fig. $5 b)$. The water temperature reached over $25^{\circ} \mathrm{C}$ in summer, and in winter, a minimum of $15^{\circ} \mathrm{C}$ was reached (Fig. 5b); changes were not spatially variable along the reservoir $\left(\mathrm{F}_{(2,33)} ; \mathrm{r}^{2}=0.04 ; \mathrm{p}=0.46\right)$. Water inflow tended to be lower in autumn and winter and higher in the summer; however, a steep increase in water inflow between August and October from $20 \mathrm{~m}^{3} / \mathrm{s}$ to $96.5 \mathrm{~m}^{3} / \mathrm{s}$ should be noted (Fig. $5 \mathrm{~b}$ ). Water inflow was highly correlated with the turbine discharge from Passo Fundo HPP $(r=0.76)$. Rainfall did not present a clear seasonal pattern during the study period (Fig. 5c) or a strong correlation with other environmental variables $(r>0.7)$.

The model selection procedure indicated that the best model of the relationship between the environmental variables and the net displacement had only one predictor variable: inflow (delta values $<2$; weight $=0.939$; Tab. 2 ). In this model, net displacement tended to increase with inflow (standardized coefficient $=0.14$ ), and inflow had greater importance than both water temperature and rainfall (Tab. 3 ). The other models could not compete with this model (delta values $>2$; Tab. 2).
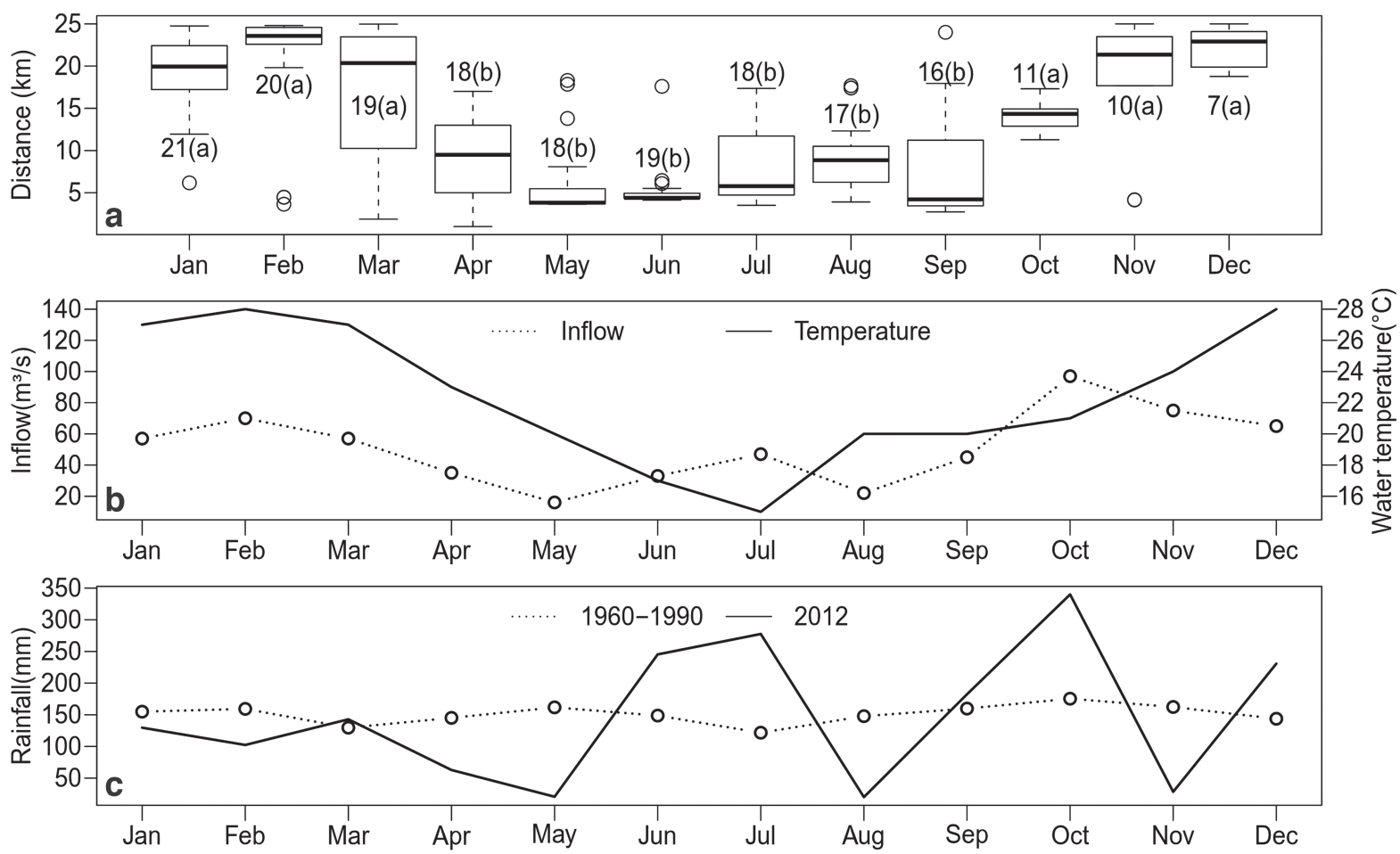

Fig. 5. a. Distance traveled by dourados (Salminus brasiliensis) from the dam in the study area. Numbers above the plots are the number of individuals. Letters above the plots represent differences or similarities according to Tukey's test, which was performed after a linear mixed effect model $(\mathrm{F}=16.5 ; \mathrm{p}<0.0001)$. Circles represent outlier values; the heavy horizontal line crossing the box is the median; the bottom and top of the box are the lower and upper quartiles, respectively; and the whiskers are the minimum and maximum values. b. Inflow $\left(\mathrm{m}^{3} / \mathrm{s}\right)$ and water temperature $\left({ }^{\circ} \mathrm{C}\right)$ in the Monjolinho reservoir during the study period (January to December 2012). c. Rainfall ( $\mathrm{mm}$ ) in the study area, showing measurements taken between January and December 2012 and historical rainfall patterns (1961-1990). 

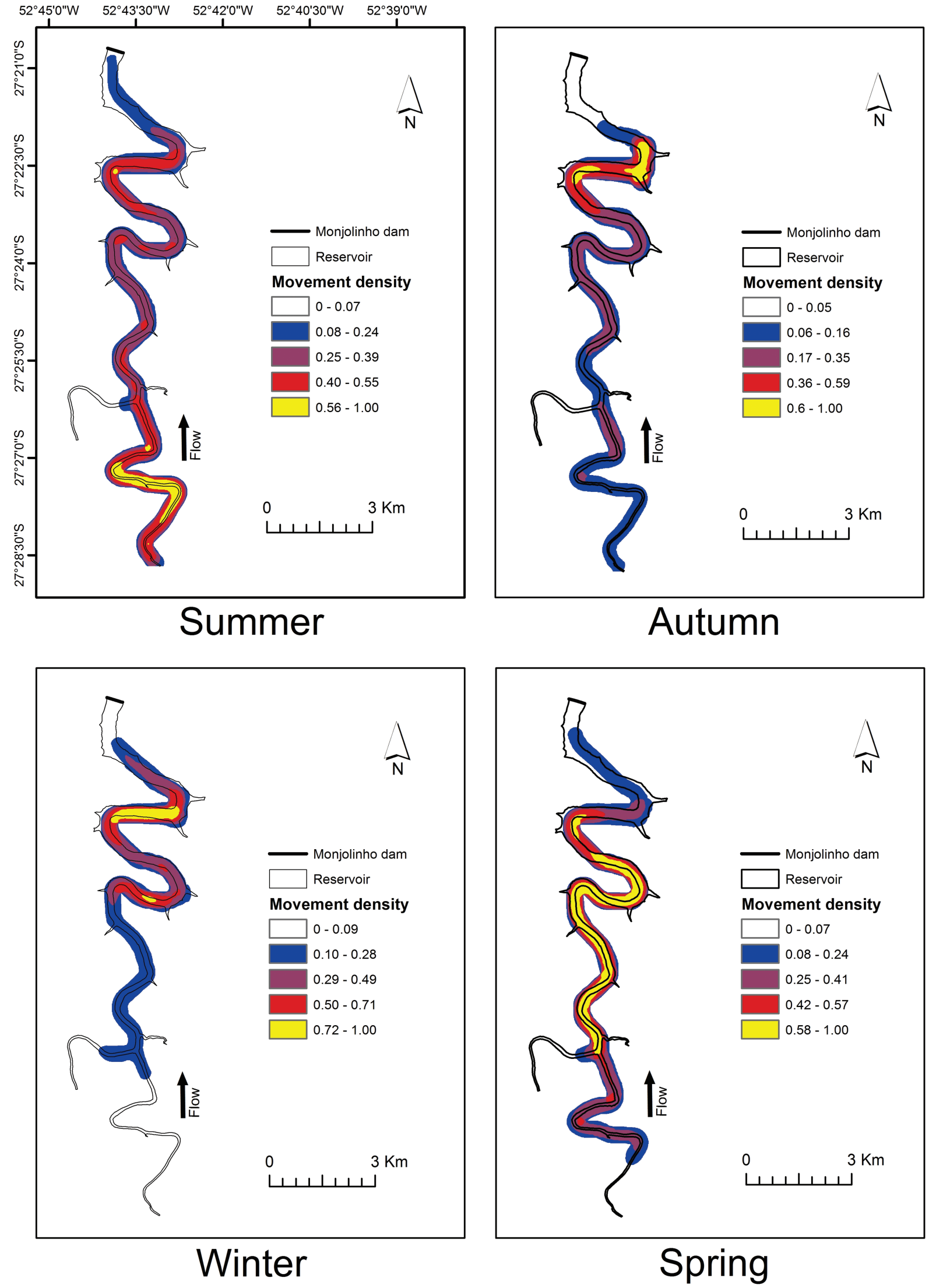

Fig. 6. Line density results showing the movement patterns of dourados (Salminus brasiliensis) in the Monjolinho reservoir. Summer $=$ January to March; Autumn $=$ April to June; Winter $=$ July to September; and Spring $=$ October to December. 
Selection of the best model for the relationship between the environmental variables and the longitudinal position (distance from the dam) of individuals yielded one best fit model (delta values $<2$ ) with inflow and water temperature (weight $=0.932 ;$ Tab. 2 ). Individual distance from the dam showed a tendency to increase with water temperature (standardized coefficient $=0.32$ ) and inflow (standardized coefficient $=0.18$ ). Both water temperature and inflow were shown to be of greater importance than rainfall (Tab. 3).

Tab. 2. Models explaining the movement of Salminus brasiliensis and their distance from the dam in the Monjolinho reservoir. AICc, Akaike information criteria for small sample sizes.

\begin{tabular}{|c|c|c|c|c|}
\hline Model & Variables & $\mathrm{AICc}$ & Delta & Weigh \\
\hline \multirow{5}{*}{$\begin{array}{l}\text { Net } \\
\text { displacement }\end{array}$} & Inflow & 85.1 & 0 & 0.939 \\
\hline & Inflow + Rainfall & 91.4 & 6.37 & 0.039 \\
\hline & Water temperature + Inflow & 92.7 & 7.66 & 0.020 \\
\hline & Inflow + Rainfall + Water Temperature & 97.9 & 12.86 & 0.002 \\
\hline & Water Temperature + Rainfall & 101.1 & 16.04 & 0.000 \\
\hline \multirow{5}{*}{$\begin{array}{l}\text { Distance } \\
\text { from the } \\
\text { dam }\end{array}$} & Inflow+Water Temperature & 338.7 & 0 & 0.932 \\
\hline & Inflow+Rainfall+Water Temperature & 344.2 & 5.51 & 0.05 \\
\hline & Water Temperature + Rainfall & 349.4 & 10.63 & 0.005 \\
\hline & Water Temperature & 349.8 & 11.09 & 0.004 \\
\hline & Inflow + Rainfall & 360.1 & 21.40 & 0.000 \\
\hline
\end{tabular}

Tab. 3. Relative variable importance* in the models of the individual net displacement and distance from the dam of Salminus brasiliensis. WT: water temperature, I: inflow, R: rainfall. *Sum of Akaike weights over all models including the explanatory variable.

\begin{tabular}{lcc}
\hline \multirow{2}{*}{ Variables } & \multicolumn{2}{c}{ Importance } \\
\cline { 2 - 3 } & Net displacement & Distance from the dam \\
\hline Inflow & 1 & 0.99 \\
Rainfall & 0.04 & 0.06 \\
Water Temperature & 0.02 & 1 \\
\hline
\end{tabular}

\section{Discussion}

Upstream and downstream movements. The results of this study showed that most of the fish released into the reservoir $(75 \%)$ were successful in finding their way upstream and out of the reservoir, taking (on average) 16.6 days to move $25 \mathrm{~km}$ upstream. However, the movements to return downstream were much less successful. Clearly, there was a decrease in the number of fish that approached the dam (downstream maximum position $<0.5 \mathrm{~km}=33.3 \%$ of all specimens; position $<0.25 \mathrm{~km}=29.1 \%$; position $<0.10$ $\mathrm{km}=20.8 \%$ ), and very few fish passed the dam downstream $(-0.2 \mathrm{~km}=8.33 \%$; see Tab. 1$)$. We assume that proximity to the dam increases the probability that a fish can find the dam and pass through the spillway or turbine towards the downstream river segment. If fish do not get close to the dam in the first place, the effectiveness of downstream migration will be hampered. Most other individuals remained in the middle and upper sections of the reservoir at least $5 \mathrm{~km}$ from the dam throughout the year, implying a lower probability of finding and passing the dam in the downstream direction.

These results are generally consistent with those of Pelicice et al. (2015), who suggested that reservoirs are unfavorable environments for adult migratory fish, preventing their downstream displacement. According to those authors, the density distribution of adults within large reservoirs should be expected to decrease abruptly in the downstream direction as a consequence of the horizontal hydraulic and limnological gradient in the reservoir affecting fish behavior and orientation. Pelicice et al. (2015) suggested that (i) migratory fish "remain in the upper reaches of impoundments and have low abundance in the reservoir" and (ii) "adult fish actively avoid inner areas of the reservoir". We observed that although fish used a large part of the reservoir (including the middle and upper transitional sections), the movement density was much lower close to the dam (less than $<3 \mathrm{~km}$ ).

However, we also found that individuals spent more time within the reservoir than outside it, tending to remain in the middle and upper sections for most of the year, which seemed inconsistent with prediction $i i$ (see above). It should be noted that the upper reservoir section $(24 \mathrm{~km}$ from the dam) is a transitional river-reservoir environment, so the limit between the reservoir and river is unclear, resulting in some uncertainty in assigning records at this section as "inside the reservoir". However, the movement density showed that year-round, except for summer, tagged fish were active inside the reservoir, including in the middle and lower sections. These fish could have been trying to move back to the river segment downstream of the reservoir but were unable to find their way through the reservoir or to bypass the dam and then remained in the reservoir. Downstream movement may have also been limited by hydrological or limnological conditions in the reservoir; however, we do not have data to make further inferences. We suggest two possible causes for fish to remain in the reservoir. First, the habitat in the free-flowing section of the Erechim River, which is upstream from the Passo Fundo HPP powerhouse, is insufficient and of poor quality. The original forest cover in this area has been largely converted to agricultural use, and there is only a relatively short $(40 \mathrm{~km})$ upstream freeflowing river stretch, which could be insufficient for the species during spawning migration. This unsuitability of the habitats for spawning upstream of the reservoir seems to be a plausible possibility because eggs and larvae of migratory fish species were never found during a 4-year ichthyoplankton monitoring program in the study area and in the Erechim River (LDF, Alexandre Cardoso, unpublished data). Second, disorientation occurs when returning to the reservoir from the upstream free-flowing sections or due to being unable to pass the dam, as suggested in other studies (Pelicice, Agostinho, 2008; Agostinho et al., 2011; Pelicice et al., 2015). 
We note, however, that most evidence on the limitation of downstream migratory movement by dams was obtained at large reservoirs, where the lentic environment is in strong contrast with lotic conditions of upstream river segments (e.g., Agostinho et al., 1999; Antonio et al., 2007; Makrakis et al., 2007a, 2007b; Agostinho et al., 2011; Makrakis et al., 2012). The Monjolinho reservoir $\left(5.46 \mathrm{~km}^{2}\right)$ is comparatively small in the range of reservoirs in large Brazilian rivers (in a total of 66 reservoirs, $78 \%$ are larger than $50 \mathrm{~km}^{2}$ Pelicice et al., 2015). Thus, our results indicate that even these small waterbodies can be unfavorable for migratory fish movements (see also Britto, Carvalho, 2013). Pompeu (2005) observed that migratory fish (Brycon sp., Leporinus spp., Prochilodus spp.) were able to move upstream, but only $0.24 \%$ moved downstream of the dam through the spillway or turbines (Santa Clara HPP reservoir; length $=15 \mathrm{~km}$; area $=7.3 \mathrm{~km}^{2}$ ). Britto, Carvalho (2013) observed that fish tended to remain in the upper reservoir sections and that the return movements of Salminus, Prochilodus, and Leporinus were negatively affected by the reservoir body (Canoas 1 and Canoas 2 HPP; lengths of $40 \mathrm{~km}$ and $32 \mathrm{~km}$, respectively). Ribeiro (2013) observed that downstream movements in the Itutinga HPP reservoir (length $<10 \mathrm{~km}$; area $=1.62 \mathrm{~km}^{2}$ ) were achieved by $31 \%$ of all tagged $P$. lineatus individuals and by $72 \%$ of all tagged Piaractus mesopotamicus individuals.

Influence of abiotic factors. Conceptual life cycle models of Neotropical migratory fish indicate that upstream spawning migration occurs in summer, which is associated with rainfall, increasing water flow and water temperature (Agostinho et al., 2003; Sato, Godinho, 2003; Godinho, Kynard, 2008; Barthem et al., 2017; Lopes et al., 2018, 2019). On the other hand, postspawning migration and return to feeding habitats occur when temperature and flow are decreasing. Our results, particularly on the longitudinal position within the reservoir, seem consistent with this pattern, suggesting that migratory movements of $S$ brasiliensis in the study area are related to seasonal variation in water temperature and flow. This means that the movement patterns of tagged fish correspond to those observed for fish in undammed rivers and reinforces the idea that restriction of movement in the downstream direction is caused by the reservoir and the dam.

Individual movements. In a population of migratory fish species, individual movement patterns can be highly variable (Makrakis et al., 2012). In the Monjolinho reservoir, dourados also exhibited diverse movement patterns, with some individuals presenting almost no movement, while others were highly active (moving up to $24 \mathrm{~km} /$ day). In our study, the most mobile individuals within the reservoir moved for distances similar to those recorded in free-flowing river stretches, from $21 \mathrm{~km}$ (Bonetto et al., 1971; Delfino, Baigún, 1985) to $63 \mathrm{~km}$ in one day (Hahn et al., 2011). Movements of less than $5 \mathrm{~km}$ /day have also been recorded in both small (Pompeu, 2005; Britto, Carvalho, 2013) and large reservoirs (Antonio et al., 2007; Makrakis et al., 2012). One possible explanation for this high interindividual variability in the movement of dourados is that some fish taken from lotic river segments, once released in the reservoir, become disoriented (Antonio et al., 2007; Lopes, 2017). It should be noted that net displacement values based on positions recorded after large time intervals (e.g., Fig. 3, $c$ and $d$ ) are only informative of fish position change within the reservoir but do not represent precise estimates of movement velocity, as multiple up and down displacements may have occurred. Consequently, net displacement values should not be interpreted as total movement activity, particularly if measured after wide time intervals since they can largely underestimate the total accumulated distance that a fish moved. For the short net distances $(<5 \mathrm{~km})$ recorded, there are two possible explanations, implying that these values should be interpreted with caution: these low values could be indicative of either fish that remained in the same area for long periods of time or of fish that moved widely but ended up in their first recorded position.

Conclusions and implications. In this study, we found that migratory $S$. brasiliensis are able to move upstream and leave the reservoir, but their downstream movement is negatively affected. Although smaller reservoirs are believed not to affect migratory movements because the limnological gradients can be much shorter or weaker than those of large reservoirs (Pelicice et al., 2015), the present results indicate that they may also pose problems to fish migration, particularly in downstream movements. This may occur because these fish avoid reservoir sections close to the dam (or are unable to find the way to pass downstream). Reservoirs less than $50 \mathrm{~km}^{2}$ are now widely distributed along many rivers (Couto, Olden, 2018), and studies at large spatial scales are necessary to understand whether the conservation of migratory fish is feasible in such fragmented rivers. It is worth noting that even a "small reservoir" (from the anthropic point of view, but perhaps not from a fish point of view) may pose a problem for both the downstream and upstream movements of migratory fish. Small reservoirs can potentially be managed to facilitate the downstream movement of adult fish, possibly by regulating overspill flow, which should be further investigated. Finally, we suggest that the impact of reservoirs that are usually considered "small" by environmental agencies (comparatively to very large reservoirs) should be objectively addressed in environmental assessments and management.

\section{Acknowledgments}

This project was funded by Monel Monjolinho Energética and Neotropical Environmental Consulting. We thank Marcos Krieger for providing the technical data from the Monjolinho HPP. We are grateful to Paulo dos S. Pompeu, Renato Silvano, Clarice B. Fialho, and four anonymous referees for suggestions that improved earlier versions of the 
manuscript. We also thank Fernando M. Pelicice for critical revision and insightful suggestions. Taís F. R. Guimarães and Renato Bolson Dala-Corte provided support in the data analysis. This study resulted from the MSc. Project of Lucas C. C. De Fries, who received a CAPES scholarship. Sandra M. Hartz received a CNPq research grant (process 306816/2010-5).

\section{References}

Agência Nacional de Águas, Sistema de Informações Hidrológicas (ANA/Hidroweb). [updated 2014 April]. Available from: http:// hidroweb.ana.gov.br/default.asp

Agostinho AA, Gomes LC, Suzuki HI, Júlio HFJ. Migratory fishes of upper Paraná river basin Brazil. In: Carolsfeld J, Harvey B, Ross C, Baer A, editors. Migratory fishes of South America: biology, fisheries and conservation status. Ottawa: World Fisheries Trust/World Bank/IDRC; 2003. p.19-98.

Agostinho AA, Miranda LE, Bini LM, Gomes LC, Thomaz SM, Suzuki HI. Patterns of colonization in neotropical reservoirs, and prognoses on aging. In: Tundisi JG, Straskraba M, editors. Theoretical reservoir ecology and its applications. Leiden: Backhuys Publishers; 1999. p.227-65.

Agostinho AA, Pelicice FM, Gomes LC. Dams and the fish fauna of the Neotropical region: impacts and management related to diversity and fisheries. Braz J Biol. 2008; 68(4):1119-32. http://dx.doi.org/10.1590/S1519-69842008000500019

Agostinho CS, Pelicice FM, Marques EE, Soares AB, Almeida DAA. All that goes up must come down? Absence of downstream passage through a fish ladder in a large Amazonian river. Hydrobiol. 2011; 675:1-12. https://doi.org/10.1007/ s10750-011-0787-0

Alves CBM, Silva LGM, Godinho AL. Radiotelemetry of a female jaú, Zungaro jahu (Ihering, 1898) (Siluriformes: Pimelodidae), passed upstream of Funil Dam, rio Grande, Brazil. Neot Ichthyol. 2007; 5(2):229-32. http://dx.doi.org/10.1590/S167962252007000200018

Antonio RR, Agostinho AA, Pelicice FM, Bailly D, Okada EK, Dias JHP. Blockage of migration routes by dam construction: can migratory fishes find alternative routes? Neotrop Ichthyol. 2007; 5(2):177-84. http://dx.doi.org/10.1590/S167962252007000200012

Barthem RB, Goulding M, Leite RG, Cañas C, Forsberg B, Venticinque E, Petry P, Ribeiro MLB, Chuctaya J, Mercado A. Goliath catfish spawning the far western Amazon confirmed by the distribution of mature adults, drifting larvae and migrating juveniles. Sci Rep. 2017; 7(41784):1-13. http://dx.doi. org/10.1038/srep41784

Bartoń K. MuMIn: Multi-model inference. R-package version 1(15).6. 2019[update 2019 March]. Available from: http:// http:cran.r-project.org/web/packages/MuMIn

Bates D, Maechler M, Bolker B, Walker S. Package lme4: linear mixed-effects models using Eigen and S4. R package version 1(7); 2014.

Becker RA, Chambers JM, Wilks AR. The New S Language. Pacific Grove: Wadsworth \& Brooks/Cole; 1988.
Bonetto AA, Pignalberi C, de Yuan EC, Oliveros O. Informaciones complementarias sobre migraciones de peces en la cuenca del Plata. Physis. 1971; 30(81):505-20.

Britto SGC, Carvalho ED. Reproductive migration of fish and management in a series of reservoirs in the Upper Parana River basin, Brazil. Fish Man Ecol. 2013; 20(5):426-33. https://doi. org/10.1111/fme. 12030

Burnham KP, Anderson DR. Model selection and multimodel inference. A practical information-theoric approach. 2 ed. New York: Springer-Verlag; 2002.

Couto TBA, Olden JD. Global proliferation of small hydropower plants - science and policy. Front Ecol Environ. 2018; 16(2):91-100. https://doi.org/10.1002/fee. 1746

Delfino R, Baigún CR. Marcaciones de peces en el embalse de Salto Grande, río Uruguay (Argentina-Uruguay). Rev Asoc Cienc Nat Litoral. 1985; 16(1):85-93.

Fundação Instituto Brasileiro de Geografia e Estatística (IBGE). Geografia do Brasil, Região Sul. Rio de Janeiro; 1990.

Fundação Zoobotânica do Rio Grande do Sul (FZB). Lista das espécies de fauna ameaçada do estado do Rio Grande do Sul. 2014[update 2017 December]. Available from: http://www. fzb.rs.gov.br/upload/2014090911580809_09_2014_especies_ ameacadas.pdf

Godinho AL, Kynard B. Migratory fishes of Brazil: life history and fish passage needs. River Res Appl. 2008; 25(6):702-12. https://doi.org/10.1002/rra.1180

Godoy MP. Peixes do Brasil - sub-ordem Characoidei: Bacia do rio Mogi Guassu. Piracicaba: Franciscana; 1975.

Gubiani EA, Gomes LC, Agostinho AA, Baumgartner G. Variations in fish assemblages in a tributary of the upper Paraná river, Brazil: A comparison between pre and post-closure phases of dams. River Res Appl. 2010; 26(7):848-65. http://dx.doi. org/10.1002/rra.1298

Hahn L, Agostinho AA, English KK, Carosfeld J, Câmara LF, Cooke SJ. Use of radiotelemetry to track threatened dourado Salminus brasiliensis in the upper Uruguay River, Brazil. Endanger Species Res. 2011; 15:103-14. http://dx.doi. org/10.3354/esr00363

Horthorn T, Bretz F, Westfall P. Simultaneous inference in general parametric models. Biom J. 2008; 50(3):346-63. https://doi. org/10.1002/bimj.200810425

Kuznetsova A, Brockhoff PB, Christensen RHB. Package 'ImerTest'. R package version. 2015.

Lima FCT, Malabarba LR, Buckup PA, Silva JFP, Vari RP, Harold A, Benine R, Oyakawa OT, Pavanelli CS, Menezes NA, Lucena CAS, Malabarba MCSL, Lucena ZMS, Reis RE, Langeani F, Casatti L, Bertaco VA, Moreira C, Lucinda PHF. Genera Incertae Sedis in Characidae. In: Reis RE, Kullander SO, Ferrari CJ, editors. Check List of the Freshwater Fishes of South and Central America. Porto Alegre: Edipucrs; 2003. p.106-69.

Lopes JM. Dinâmica migratória e reprodutiva de uma espécie reofílica de peixe (Prochilodus costatus) no Alto São Francisco, MG: diferenças entre populações locais e transpostas e implicações para a instalação de um sistema de transposição de peixes na UHE Três Marias. [PhD Thesis]. Lavras, MG: Universidade Federal de Lavras; 2017. 
Lopes JM, Alves CBM, Peressin A, Pompeu PS. Influence of rainfall, hydrological fluctuations, and lunar phase on spawing migration timing of the Neotropical fish Prochilodus costatus. Hydrobiol. 2018; 818(1):145-61. https://doi.org/10.1007/ s10750-018-3601-4

Lopes JM, Pompeu PS, Alves CBM, Peressin A, Prado IG, Suzuki FM, Facchin S, Kalapothakis E. The critical importance of an undammed river segment to the reproductive cycle of a migratory Neotropical fish. Ecol Freshw Fish. 2019; 28(2):302-16. https://doi.org/10.1111/eff.12454

Makrakis MC, Miranda LE, Makrakis S, Fernandez DR, Garcia JO, Dias JHP. Movement patterns of armado, Pterodorus granulosus, in the Paraná River Basin. Ecol Freshw Fish. 2007a; 16(3):410-16. https://doi.org/10.1111/j.16000633.2007.00238.x

Makrakis MC, Miranda LE, Makrakis S, Fontes HMJ, Morlis WG, Dias JHP, Garcia JO. Diversity in migratory patterns among Neotropical fishes in a highly regulated river basin. J Fish Biol. 2012; 81(2):866-81. http://dx.doi.org/10.1111/j.10958649.2012.03346.x

Makrakis MC, Miranda LE, Makrakis S, Xavier AMM, Fontes HM, Morlis WG. Migratory movements of pacu, Piaractus mesopotamicus, in the highly impounded Paraná River. J Appl Ichthyol. 2007b; 23(6):700-04. https://doi.org/10.1111/j.14390426.2007.01006.x

Nilsson C, Reidy CA, Dynesius M, Revenga C. Fragmentation and flow regulation of the world's large river systems. Science. 2005; 308(5720):405-08. http://dx.doi.org/10.1126/ science. 1107887

Noonan MJ, Grant JWA, Jackson CD. A quantitative assessment of fish passage efficiency. Fish Fish. 2012; 13(4):450-64. https:// doi.org/10.1111/j.1467-2979.2011.00445.x

Pelicice FM, Agostinho AA. Fish-passage facilities as ecological traps in large neotropical rivers. Conserv Biol. 2008; 22(1):180 88. https://doi.org/10.1111/j.1523-1739.2007.00849.x
Pelicice FM, Pompeu PS, Agostinho AA. Large reservoirs as ecological barriers to downstream movements of Neotropical migratory fish. Fish Fish. 2015; 16(4):697-715. https://doi. org/10.1111/faf.12089

Pompeu PS. Estudo da regra operativa e avaliação de um mecanismo de transposição de peixes do tipo elevador com caminhão tanque. [PhD These]. Belo Horizonte, MG: Universidade Federal de Minas Gerais; 2005.

Pompeu PS, Agostinho AA, Pelicice FM. Existing and future challenges: the concept of successful fish passage in South America. River Res Appl. 2012; 28(4):504-12. https://doi. org/10.1002/rra.1557

$\mathrm{R}$ Development Core Team. language and environment for statistical computing. 2019. Available from: http://www.Rproject.org.

Reis RE, Lucena ZMS, Lucena CAS, Malabarba LR. Peixes. In: Fontana CS, Bencke GA, Reis RE, editors. Livro vermelho da fauna ameaçada de extinção no Rio Grande do Sul. Porto Alegre, Edipucrs; 2003. p.117-45.

Ribeiro TC. Migração de peixes neotropicais em rio com barramentos sucessivos. [PhD These]. Belo Horizonte, MG: Universidade Federal de Minas Gerais; 2013.

Sato Y, Godinho HP. Migratory fishes of the São Francisco River. In: Carolsfeld J, Harvey B, Ross C, Baer A, editors. Migratory fishes of South America: biology, fisheries and conservation status. Ottawa: World Fisheries Trust/World Bank/IDRC; 2003. p.195-232.

Sverlij SB, Ros AE. El dorado, Salminus maxillosus (Pisces, Characiformes) en el Río de La Plata y Río Uruguay inferior. Rev Invest Des Pesq. 1986; 6:57-75.

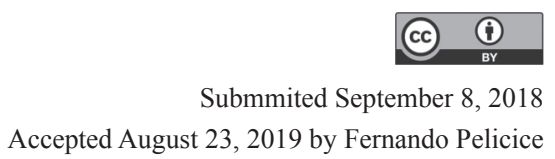
Accepted August 23, 2019 by Fernando Pelicice

\section{ERRATA}

In the article "Movement and longitudinal distribution of a migratory fish (Salminus brasiliensis) in a small reservoir in southern Brazil", with DOI: 10.1590/1982-0224-20180119, published in the journal Neotropical Ichthyology, 17(3): e180119, page e180119[1], Table of Contents:

Where read: Fries, Lucas De

Should read: De Fries, Lucas 